\title{
College-goers Psychographic Shopping Behavior towards Luxury Fashion in India
}

\author{
Massarat Ghazal, Jha Suchita
}

\begin{abstract}
In India as well as globally the usage of fashion apparel is an integral part of college-goers lifestyle. The present study tries to explore the buying behavior pattern of clothing of students in India with respect to demographic factors like gender and income. The study is conducted among the post graduate students studying in Pune. From the sample data collected it was noticed that buying behavior of clothing is same across the different income and social classes of teenagers. The data collection is done with structured questionnaire and focus group interview. Analysis of the data suggested the fact that there is significant difference in behavior noted with various demographic factors.
\end{abstract}

\section{Key Words: Clothing, College-goers, Buying behavior}

\section{INTRODUCTION}

Today in this consumer-based society, fashion has become a necessitous part of us. Whenever we talk about fashion, clothing takes the most important role in defining fashion. Every day youth spends a lot of time to decide about clothes they should wear. If we look in to the behavior of young generation they feel clothing is an important aspect of personality so they give lot of importance to clothing on various occasions, thus it is very important to study clothing purchase behavior of teenagers and college-goers not only because they are the trendsetters and opinion leaders for dress and living styles (P Goswami, 2007) but to get an insight on what determines their purchase intentions. Clothing purchases are the biggest expenditure in a young person's budget (Sarikisian-Miller, 2003) and more than 85 per cent of teenagers have a major say in buying decisions of clothes (Tootelian and Windeshausen, 1976).

If we look into Indian population young consumers in the age group 15-30 represents $35 \%$ of the total population in India \& it is expected that 300 million more youth will join the workforce by 2025 .

Indian apparel industry is projected to grow at $15 \%$ CAGR (Euromonitor, 2016). The youth or Generation Y is considered a major consumer segment receptive towards globalization trends and is thus the focus of much attention for marketers. Recent years have seen the intermingling of traditional Indian values with western values and Indians are adopting global brands as a symbol of global value-system.

Revised Manuscript Received on March 2, 2020.

* Correspondence Author

Dr.Ghazal Massarat *, Dean \& Associate professor in Syscoms College, Abu Dhabi, UAE.Mobile: +971 553784420, Email: ghazal.iiml@gmail.com, Dean@syscomscollege.com

Dr.Suchita Jha, Assistant Professor, Symbiosis Institute of International Business, Symbiosis International (Deemed University), Hinjewadi, Pune, Maharashtra, India. Email: suchita.jha@siib.ac.in
Indian consumers' aspirations and values are group dominated and social acceptance is given high priority. (Khare, \& Rakesh, 2010). Researchers suggested that buying behavior of clothing by teenagers depends on their income and social class (Nandini, Jeevananda 2014)

\section{LITERATURE REVIEW \& HYPOTHESES}

The present paper is based on two major theories to establish the study hypotheses. The first theory is "theory of reasoned action" or TRA (Fishbein and Ajzen, 1975) and its extension, the second theory is "theory of planned behavior" or TPB (Ajzen, 1985). According to TRA and TPB, the actual behavior of youngsters would be determined by his/her behavioral intention $n$ (i.e. the cognitive representation of the consumer's motivation to enact a specific behavior, such as browsing or purchase).The TPB has been used in multiple contexts in retailing research such as luxury fashion (Gao et al., 2009a). The shoppers' demographics majorly influence the clothing purchase behavior. TPB has been criticized on the grounds that the knowledge of a customer's attitude towards a brand may not always be a good predictor of his/her actual behavior (Solomon et al., 2002; Newman and Foxall, 2003). Thus, it may not always explain all consumer phenomena in retailing. Thereby one more theory the theory of shopping preference theory (Peck and Childers, 2003, 2006) been used to analyze the buying behavior among youth. This theory suggest that consumer's preference and buying behavior at a store may be influenced by non-functional elements, such as enjoyment and sensory gratification. In addition, demographic factors such as gender age social class may affect shopping orientations, time spent in store. Shopping preference theory also suggests that psychographic characteristics, such as personality and self-concept, could help marketers understand the buying behavior among youth. Younger generation see cloth shopping as a pleasure and fun-seeking activity ("cool") and believe fashion stores are stylish, authentic, desirable, unique, and innovative. (Roy, Sethuraman, Saran , 2016).

\section{A. Consumer age \& cloth purchase behavior}

We have seen from the previous study that younger consumers to be more prone towards cloth purchase than older consumers, some researchers have also found that female consumers are more oriented towards cloth purchasing. Interestingly, there have been some studies that investigated the joint effect of demographic factors on behavioral variables such as purchase intentions and found specific gender and age group on this we can infer that consumer demographics 


\section{College-goers Psychographic Shopping Behavior towards Luxury Fashion in India}

would influence cloth purchasing. Piacentini \& Mailer et al. (2004) indicated that teenagers from wealthier families having more disposable money are less likely to be involved in status consumption.

On the other hand, teenagers from the lower and middle social classes are more likely to be involved in status consumption to display their "wealth". Consistent with studies (Eastman, 2011; O'Cass \& Frost et al. 2002) status seeking consumers can come from any income or social class level. On the contrary, Chao \& Schor, (1998) demonstrated in a study on cosmetics that the status seeking consumers are mostly Caucasian, higher in education and income, and live in urban communities. Further, Deeter-Schmelz, Moore \& Geobel, (2000) ascertain that consumers' income have minimal impact on prestige concept. Younger people generally prefer a higher number of low quality, cheap and fashionable clothes, compared to the older generation which prefers to purchase a fewer number of higher quality clothes. The older consumers will see fast fashion as a waste since it means buying several garments of low quality and then throwing away older clothes as soon as the new ones hang in the closet. (Bhardwaj \& Fairhurst, 2010).

\section{B. Consumer Income \& effect on cloth purchase behavior}

Based on the above discussion on demographics, we posit:

H1: Consumer age has no effect on cloth purchase.

$\mathrm{H} 2$ : Consumer gender will have a significant effect on cloth purchase.

H3. Consumer income has a positive effect on cloth purchase.

In addition to testing the above main effect hypotheses, we explore the interaction effects of age and gender and income and gender on cloth purchase.

\section{RESEARCH GAP}

There are no studies which represent that clothing buying behavior is irrespective of income and social class.

The primary research questions for this investigation were:

$R Q 1$. Do , age, education, income of Indian youth influence their purchase intention towards clothing $R Q 2$. More specifically, which dimensions influence youth clothing purchase intention.

\section{RESEARCH OBJECTIVE}

- Evaluating the relationship between social/income class on youngsters' purchase behavior towards clothing

- To find the relationship with demographic factors like age, gender, income and cloth buying behavior.

- To find the other factors which are affecting the behavior of teenagers towards purchasing of clothes.

\section{METHODOLOGY}

We test hypotheses H1-H3 based on a survey of 130 respondents. Since our objective was to study a set of hypothesized relationships, and we had established scales for the latent constructs being studied, we adopt the survey method and factor analysis to collect data and obtain construct measures. We first describe the survey design and then the sampling and data collection procedure.

\section{A. Survey Design}

Demographic variables investigated are those commonly used in similar studies: age $(21-24 ; 25-28 ; 29-31)$, gender (male, female), and status in society (1-10). Fashion shopping frequency was measured (bi-monthly, once a month, once in 2 months, once in 6 months). Monthly spending on clothes was measured out of their total spending $(5-10 \%, 10-20 \%, 20-30 \%, 30-40 \%)$. The reason behind buying clothes was investigated which gives consumers feeling of (looking good, dressing nicely, keeping your own style, boosting confidence, comfortable clothing). Consumer's inspiration was also measured for their new purchases (Fashion blogs, celebrities, magazines, friends, and family).

\section{B. Sampling and data collection}

The population for the current study was considered to be students studying in the city of Pune enrolled either under PG programs. The target group of respondents were the students in the age group of 21-30 years. The survey was conducted over a period of 15 days, to ensure a big sample size representation from both genders and different age groups. Exploratory factor analysis was done to evaluate the various factors affecting the college goer's behavior towards fashion.

\section{ANALYSIS \& FINDINGDS}

Table 1.1

\begin{tabular}{|c|c|c|c|c|c|c|}
\hline $\begin{array}{l}\text { Anora: Tro-Factor Without } \\
\text { Replication }\end{array}$ & & & & & & \\
\hline SUMAARI & Count & Sian & Average & Variance & & \\
\hline once in a month & 2 & 80 & 40 & 200 & & \\
\hline once in 2 months & 2 & 35 & 17.5 & 3125 & & \\
\hline once in 6 months & 2 & 15 & 7.5 & 125 & & \\
\hline 21.24 & 3 & 90 & 30 & 400 & & \\
\hline 25.28 & 3 & 40 & 13.33333 & 208.3333 & & \\
\hline \multicolumn{7}{|l|}{ ANOVA } \\
\hline Solvce of Variation & SS & $d^{f}$ & ISS & $F$ & P.value & $F$ crit \\
\hline Rows & 1108333 & 2 & 554.1667 & 10.23077 & 0.089041 & 19 \\
\hline Columns & 416.6667 & 1 & 416.6667 & 7.692308 & 0.109129 & 18.51282 \\
\hline Error & 108.3333 & 2 & 54.16667 & & & \\
\hline Total & 1633333 & 5 & & & & \\
\hline
\end{tabular}

H1: Consumer age has no effect on cloth purchase.

In table 1.1 if $\mathrm{F}<\mathrm{F}$ critical or $\mathrm{P}$-value > alpha (.05), then we reject the null hypothesis, which shows that there is a relationship between both the factors, which are analyzed. Here $\mathrm{F}=10.23$ which is less than $\mathrm{F}$ crit $=19$ and $\mathrm{P}$-value $=$ .089 which is grater that alpha $=.5$, for the rows which shows that there is no significant difference between both the

It can be concluded that the consumers who are from age groups 21-24 and 25-28 have 
nearly same buying frequency ratio. Though the no. of consumers are less from age group 25-28 but have the same ratio of buying frequency.

Correlation Analysis:

Table 1.2

\begin{tabular}{|lcc|}
\hline & $21-24$ & $25-28$ \\
\hline $21-24$ & & \\
$25-28$ & 0.86 & \\
\hline
\end{tabular}

This table 1.2 shows that there is high co-relation between the age groups 21-24 and 25-28 and it can be concluded that the buying frequency is similar among the age group in graph 1.1

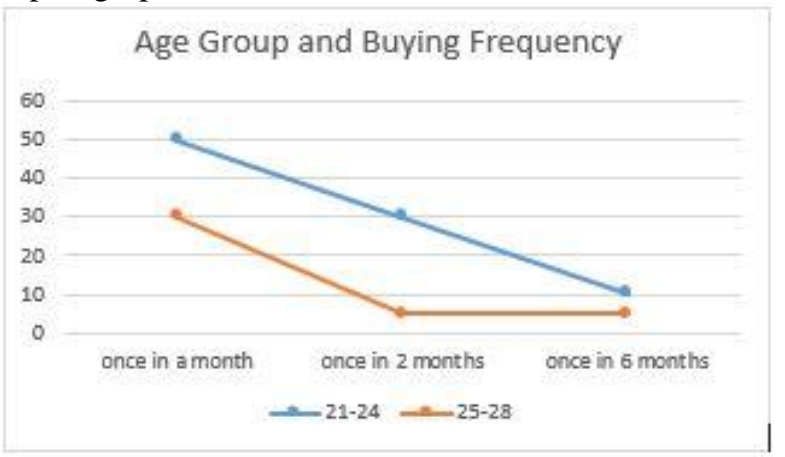

Graph 1.1

H2: Consumer gender will have a significant effect on cloth purchase.

Table 2.1

\begin{tabular}{|c|c|c|c|c|c|c|}
\hline \multicolumn{7}{|l|}{$\begin{array}{l}\text { Anova: Single Factor } \\
\text { SUMMARY }\end{array}$} \\
\hline Grolps & Count & Sum & Average & Variance & & \\
\hline Female & 4 & 61 & 1525 & 193.583 & & \\
\hline Male & 4 & 69 & 1725 & 236.917 & & \\
\hline \multicolumn{7}{|l|}{ ANOVA } \\
\hline Sowre of Variation & SS & $d$ &.$M S$ & $F$ & $P$-value & $F$ crit \\
\hline Between Groups & 8 & 1 & 8 & 0.03717 & 0.85349 & 5.98738 \\
\hline Within Groups & 1291.5 & 6 & 215.25 & & & \\
\hline Total & 1299.5 & 7 & & & & \\
\hline
\end{tabular}

Table 2.1 shows $\mathrm{F}=.037$ which is less than $\mathrm{F}$ crit $=5.98$ and $\mathrm{P}$-value $=.85$ which is grater that alpha $=.5$, for the Male and Female groups, which shows that there is no significant difference between both the groups. Though analysis of variance is much smaller but there can be significant difference in buying behavior of both the groups, which is shown below.

Correlation Analysis:

Table 2.2

\begin{tabular}{|c|c|c|c|c|}
\hline & $5-10^{\prime}$ & $10-20$ & $20-30$ & $30-40$ \\
\hline $5-10 \%$ & & & & \\
\hline $10-20 \%$ & & & & \\
\hline $20-30 \%$ & & & & \\
\hline $30-40 \%$ & & & & \\
\hline
\end{tabular}

It can concluded from table 2.2 analysis consumers who spend $5-10 \%$ and $10-20 \%$ of their monthly spending on cloth purchase have a positive relationship and consumers who spend $20-30 \%$ and $30-40 \%$ of their monthly spending on cloth purchase have a positive relationship.

Graph 2.1

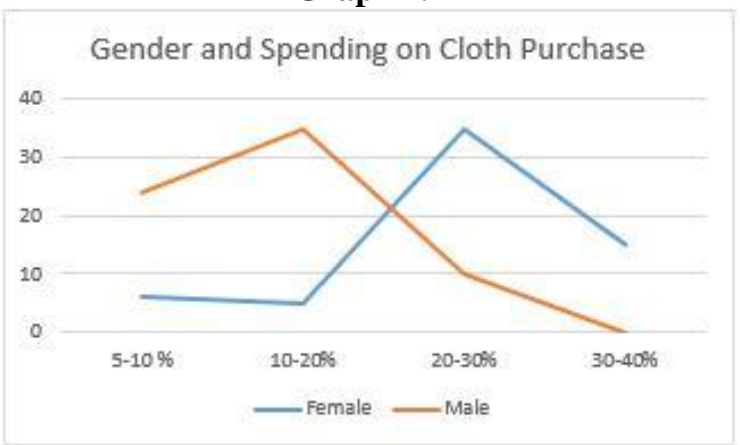

It can be concluded from this graph 2.1 that Females spend in the bracket of $20-40 \%$ towards cloth purchase whereas males spend in the bracket of 5-20\% towards cloth purchase, therefore females are more prone towards shopping of clothes.

H3: Consumer income and behavior while cloth purchase.

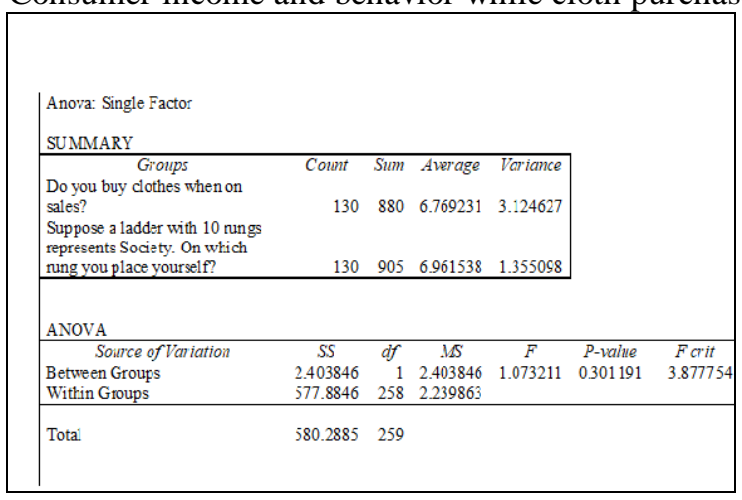

Table3.1

Table 3.1 shows that if $\mathrm{F}<\mathrm{F}$ critical or $\mathrm{P}$-value $>$ alpha (.05), then we reject the null hypothesis, which shows that there is a relationship between both the factors which are analyzed. Here $\mathrm{F}=1.07$ which is less than $\mathrm{F}$ crit $=3.87$ and $\mathrm{P}$-value $=.030$ which is greater that alpha $=.5$, which shows that there is no significant difference between both the groups.

It can be concluded that these consumers with having an average of $7^{\text {th }}$ rank in income and social class on a scale of $1-10$ with $10^{\text {th }}$ being the highest prefer to buy clothes when on sales and higher income group and social class do not have any effect on status consumption, because in this age group consumers show same habits of buying clothes.

Graph 3.1

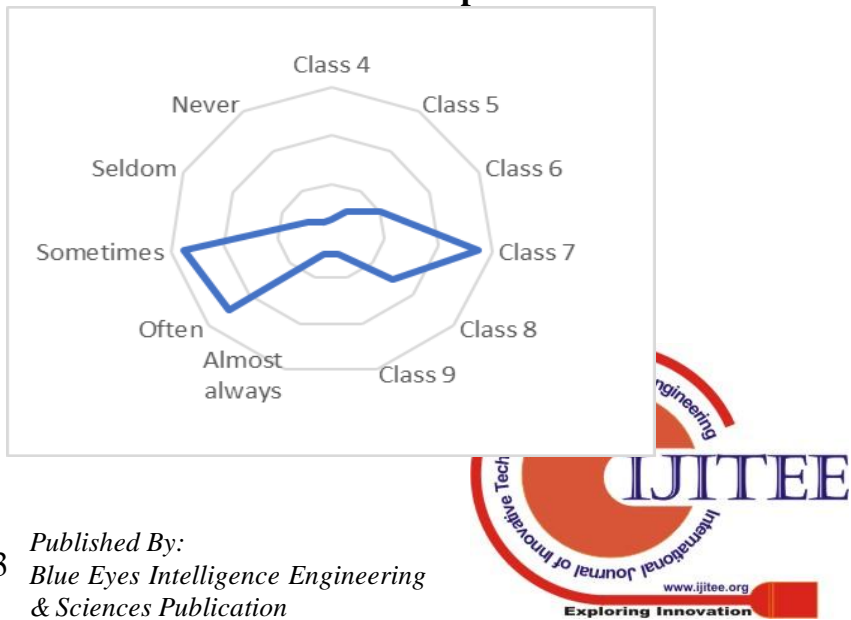




\section{College-goers Psychographic Shopping Behavior towards Luxury Fashion in India}

The graph 3.1indicates the income and social class on the right side and consumer buying behavior of clothes when on sales is there on the left side. It can be concluded that most of the consumers think that they belong to "Class 7" and they buy "Often" and "Sometimes" clothes when on sales.

\section{OTHER FINDINGS \& ANALYSIS}

Where do consumers shop from mostly for clothing?

Graph 4.1

The graph 4.1 analysis shows that consumers prefer to buy clothes from "Shopping Malls" and "Retail Stores", "Online Shopping", \& "Local owned shops" channels of shopping respectively follows it.

According to consumers, buying new clothes gives them a feeling of:

Graph 4.2

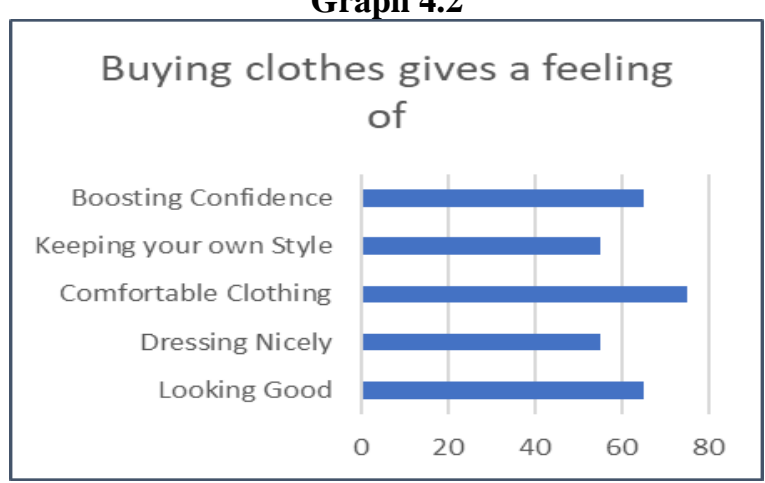

The graph 4.2 analyze the factors which drive consumers and gives them the feeling for buying clothes. It can be concluded from the graph that consumers prefer "Comfortable clothing" most when they shop and "Looking good" \& "Boosting confidence" can be the next important feeling which they get after buying clothes.

What kind of clothes consumers prefer to buy?

\section{Graph 4.3}

$\begin{aligned} & \text { What kind of clothes are preferred } \\ & \text { " Casual Wear } \\ &=\text { Formal Wear } \\ &=\text { Ethnic and Festive } \\ & \text { Wear } \\ & \text { "Sports and Active } \\ & \text { Wear } \\ &\end{aligned}$

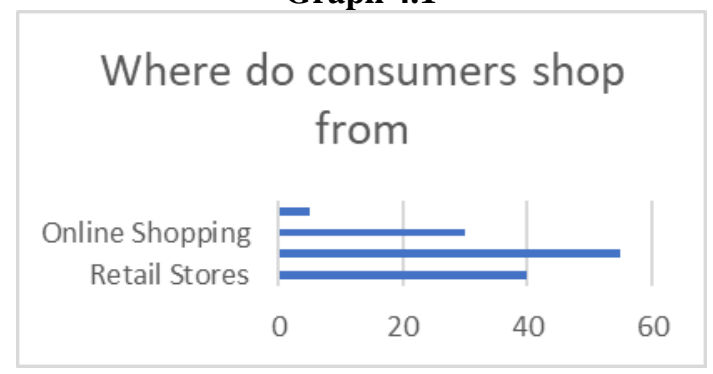

The graph 4.3 analyzes the different kind of clothes consumers prefer to buy most. It can be concluded from the graph that people in the age group of 21-31 spend more on shopping of "Casual Wear", whereas there is a huge difference between "Casual Wear" and the next preferences like "Formal Wear", "Ethnic and Festive Wear" and "Sports Wear". Though consumers

\section{CONCLISION \& DISCUSSION}

From the sample data collected it was noticed that male and female students' behavior towards purchasing clothes differ. In the previous study done by Handa, M., \& Khare, A. (2013) Young men and women differ with respect to their involvement with fashion clothing and even more with regard to their involvement with the purchase of fashion clothing, with women reporting a higher level of involvement . Our study also supported the same research that women are more involved toward clothing purchase. However, the gender roles have become fluid and flexible and fashion clothing holds similar significance to both genders this study don't accept this fact \& talks that gender do have different involvement level among Indian youth. Youth especially is extremely price-sensitive and are dependent upon their parents for financial assistance. The Indian youth starts shopping independently while studying in University and are governed by the peer groups in their purchase decisions. The purchase of global luxury clothing by the Indian youth echoes the sanction they have received from their parents for pursuing their goal of self-enhancement. Wicklund and Gollwitzer suggest that individuals self-symbolize through products and the evaluation by the members of society about their success may be based on the physical possession they own, and fashion clothing connotes success to the youth (Khare, A., \& Rakesh, S.,2010). Present study also found out that youth in general gives more importance to quality, durability, style and aesthetics over brand of the clothes as brands means more price. It was also noticed that influence of difference in income and social classes of teenagers and college-goers don't have much involvement in deciding the buying behavior of clothes. The status consumption is same in this demographic age and income group.

\section{MANAGERIAL IMPLICATION}

The research findings indicate that in a developing economy, where income levels are still not very high, and demographic profiles of the consumers indicate a greater percentage of middle-class homes, fashion products are perceived as items of social recognition and individual enhancement. The Indian youth is affected by global brands and perceive it to symbolize style and fashion trends.

The involvement of the Indian youth with fashion clothing suggests that fashion clothing is accepted as an important purchase item that is supposedly improving the overall image of the individual in groups. The study has come with certain consumer insights, which can be used by the clothing brands for young generation to design an effective marketing strategy. 
The determined factors are coming in a big way to help the clothing brand marketers to understand how Indian teenagers perceive clothing

Our study has provided an insight about the relationship between clothes buying behavior and income and social class of students. This finding is providing a consumer insight to develop the effective media campaigns to influence the buying behavior of students. So irrespective of social class they want to do similar kind of dressing so this gives an indication to brands to work on lowering the price for Indian market and youth predominately dominates the clothing market in India.

\section{REFERENCES}

1. Ajzen, (1985) "From Intentions to Actions: A Theory of Planned Behavior", Action Control, pp

2. 11-39

3. Aron O'Cass, Hmily Frost, (2002) "Status brands: examining the effects of non-product-related brand associations on status and conspicuous consumption", Journal of Product \& Brand Management, Vol. 11 Iss: 2, pp. $67-88$

4. Bhardwaj \& Fairhurst (2010), "Fast fashion: response to changes in the fashion industry", The International Review of Retail, Distribution and Consumer Research, Pages 165-173

5. Chao \& Schor, (1998) "Empirical tests of status consumption: Evidence from women's cosmetics", Journal of Economic Psychology, 1998, vol. 19 , issue 1 , pages $107-131$

6. Deeter-Schmelz, Moore \& Geobel, (2000), "Prestige Clothing Shopping by Consumers: A Confirmatory Assessment and Refinement of the Precon Scale with Managerial Implications", Journal of Marketing Theory and Practice, Vol. 8, Issue 4, Pages 43-58

7. Eastman J. Eastman K. 2011, "Perceptions of Status Consumption And The Economy", Journal of Business \& Economics Research, Volume 9, Number 7

8. Fishbein, M., \& Ajzen, I. (1975). "Belief, attitude, intention, and behavior: An introduction to theory and research."

9. Gao, L., Norton, M.J.T., Zhang, Z. and To, C.K. (2009a), "Potential niche markets for luxury

10. fashion goods in China”, Journal of Fashion Marketing and Management: An International

11. Journal, Vol. 13 No. 4, pp. 514-526

12. Gollwitzer, P. M., \& Wicklund, R. A (1981) "Symbolic self-completion and self-presentation".

13. Handa, M., \& Khare, A. (2013). Gender as a moderator of the relationship between materialism and fashion clothing involvement among Indian youth. International Journal of Consumer Studies, 37(1), 112-120.

14. Jovey Wai Kwan Leung, Gail Taylor, (2002) "Fashion buying criteria of X Generation consumers in Hong Kong", Journal of Fashion Marketing and Management: An International Journal, Vol. 6 Iss: 1, pp.63 - 76

15. Jung-Im Seo, Jan M. Hathcote, Anne L. Sweaney, (2001) "Casualwear shopping behaviour of college men in Georgia, USA", Journal of Fashion Marketing and Management: An International Journal, Vol. 5 Iss: 3, pp. $208-222$

16. Karthikeyan, S. (2011). An investigation on consumer behavior and preferences towards apparel, purchase by Indian consumers age 15-25.

17. Khare, A., \& Rakesh, S. (2010). Predictors of fashion clothing involvement among Indian youth. Journal of Targeting, Measurement and Analysis for marketing, 18(3-4), 209-220.

18. Kumar, R. V., \& Sarkar, A. (2008). Psychographic segmentation of Indian urban consumers. Journal of the Asia Pacific Economy, 13(2), 204-226

19. Mathews, S., \& Nagaraj, H. (2011). An Analytical Study of VALS of Youth-Implication to Marketers. Management convergence, 1(1), 11-23.

20. Narang, R. (2011). Examining the role of various psychographic characteristics in apparel store selection: a study on Indian youth. Young Consumers, 12(2), 133-144.

21. Nandini. R1, Dr S. Jeevananda2 (2014). To Study the Factors of Consumer Involvement in Fashion Clothing. International Journal of Science and Research (IJSR), Volume 3 Issue 7.

22. Newman, A.J. and Foxall, G.R. (2003), "In-store customer behaviour in the fashion sector: some

23. emerging methodological and theoretical directions", International Journal of Retail \&

24. Distribution Management, Vol. 31 No. 11, pp. 591-600.
25. O'Cass, A. (2004). Fashion clothing consumption: antecedents and consequences of fashion clothing involvement. European Journal of Marketing, 38(7), 869-882.

26. Peck, J. and Childers, T. (2003), "Individual differences in haptic information processing: the

27. 'need for touch' scale", Journal of Consumer Research, Vol. 30 No. 3, pp. 430-442.

28. Piacentini, M. and Mailer, G. (2004), "Symbolic consumption in teenagers' clothing choices", Journal of Consumer Behavior, Vol. $3 \mathrm{No}$ 3, pp. 251-262

29. Roy, S., \& Goswami, P. (2007). Structural equation modeling of value-psychographic trait-clothing purchase behavior: a study on the urban college-goers of India. Young Consumers, 8(4), 269-277.

30. Sarah Giovannini, Yingiiao Xu , Jane Thomas, (2015) "Luxury fashion consumption and Generation Y consumers: Self, brand consciousness, and consumption motivations ", Journal of Fashion Marketing and Management, Vol. 19 Iss: 1, pp.22 - 40

31. Solomon, M., Bamossy, G. and Askegaard, S. (2002), Consumer Behaviour - A European

32. Perspective, Pearson Education, Harlow, p. 144.

33. Sudas Roy, Paromita Goswami, (2007) "Structural equation modeling of value-psychographic trait-clothing purchase behavior: a study on the urban college-goers of India", Young Consumers, Vol. 8 Iss: 4, pp.269 277

34. Subhadip Roy, Raj Sethuraman, Rashmita Saran , (2016) "The effect of demographic and personality characteristics on fashion shopping proneness: A study of the Indian market", International Journal of Retail \& Distribution Management, Vol. 44 Iss: 4, pp.426 - 447.

\section{AUTHOR'S PROFILE}

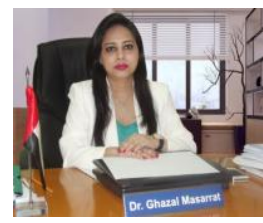

Dr. Ghazal Masarrat, is currently working as Dean \& Associate professor in Syscoms College, Abu Dhabi, UAE. She has more than 13 years of academic and research experience in reputed universities in UAE as well as in India. She also contribute as Academic consultant for Medicom consultancy ltd. Dr. Masarrat was awarded Obaid Bin Saif Al-Nasseri Gold Medal and University Gold Medal for outstanding performance in University. During 2002-2004 awarded University Research Fellowship by A.M.U and IOS Scholarship by Institute of Objective Studies, NGO in consultative status (Roster) with the Economic and Social Council of the United Nations. She has authored and co-authored more than two international book publications and more than 15 research papers in reputed referred national and international journals. Presented her research at national and international conferences.

Her current areas of research interest have been Consumer behavior, Marketing management, Strategic marketing, Product and brand management, Principles of management.

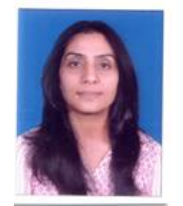

Dr. Suchita Jha, is a MBA (Marketing) and holds a Ph.D. degree in Marketing. She has worked with Aptech, Intel Teach \& KhimjiRamdas group in India \& Muscat, Oman as Marketing professional. She worked with colleges across Oman, UAE \& India with reputed colleges. She is also part of various start up consultancy on Marketing. Her research interests include Services marketing, Consumer behaviour etc. She is a reviewer of some International Journals and has published research papers in International Journals. Email: suchita.jha@siib..ac.in Phone: O: +91-20-22934314-447 M: +919004344974 